\title{
PERENCANAAN STRATEGI PENDIDIKAN DASAR PADA SDNP KOMPLEKS IKIP RAWAMANGUN JAKARTA TIMUR (ANALISIS KASUS)
}

\author{
Yufita \\ Witarsa Tambunan \\ witarsa.oke@gmail.com
}

\begin{abstract}
Abstrak
Pengembangan sikap, kemampuan, pengetahuan dan ketermapilan dasar perlu diberikan kepada peserta didik pada tingkatan pendidikan dasar untuk mempersiapkannya mengikuti pendidikan di jenjang selanjutnya. Sekolah Dasar Negeri Percontohan (SDNP) Kompleks IKIP Rawamangun Jakarta sebagai salah satu lembaga pendidikan dasar mengalami perjalanan panjang sehingga dapat menjadi sekolah percontohan. Penelitian ini merupakan suatu studi analisis Perencanaan Strategi (RENSTRA) Pendidikan pada SDNP Kompleks IKIP Rawamangun Jakarta. Penelitian ini ingin mengetahui apakah SDNP dalam pelaksanaan pengajaran pendidikan menggunakan Prencanaan Strategis. Dalam analisis yang dilakukan ternyata pendekatan perencanaan strategi dapat diterapkan pada organisasi (Sekolah) SDNP Kompleks IKIP Rawamangun Jakarta. Hal ini diperkuat dengan hasil analisis yang menggunakan analisis lingkungan maupun analisis SWOT. Dari hasil kajian ini diharapkan dapat mengingatkan lembaga pendidikan yang ada untuk menggunakan pendekatan Perencanaan Stratedi atau Pendekatan Total Quality (TOM) dalam upaya peningkatan mutu sekolah.
\end{abstract}

Kata kunci : Analisa SWOT, Rencana Strategi 


\begin{abstract}
The development of basic attitudes, abilities, knowledge and skills needs to be provided to students at the basic education level to prepare them for education at the next level. The Pilot Public Primary School (SDNP) of the IKIP Rawamangun Jakarta Complex as one of the basic education institutions has had a long way to go so that it can become a pilot school. This research is an analysis study of Educational Strategy Planning (RENSTRA) at SDNP Kompleks IKIP Rawamangun Jakarta. This study wanted to find out whether SDNP in the implementation of education teaching uses Strategic Planning. In the analysis carried out, it turns out that the strategic planning approach can be applied to the organization (School) SDNP Kompleks IKIP Rawamangun Jakarta. This is reinforced by the results of the analysis using environmental analysis and SWOT analysis. From the results of this study, it is hoped that it can remind existing educational institutions to use the Strategic Planning approach or the Total Quality Approach (TOM) in an effort to improve school quality.
\end{abstract}

Keywords: SWOT analysis, Strategy Planning 


\section{A. Pendahuluan}

\section{Latar Belakang}

Pembukaan Undang-Undang Dasar Negara Republik Indonesia tahun 1945 mengamanatkan Pemerintah Negara Indonesia yang melindungi segenap bangsa Indonesia dan seluruh tumpah darah Indonesia dan untuk memajukan kesejahteraan umum, mencerdaskan kehidupan bangsa, dan ikut melaksanakan ketertiban dunia yang berdasarkan kemerdekaan, perdamaian abadi dan keadilan sosial . Selanjutnya Undang-Undang Dasar Negara Republik Indonesia Tahun 1945 mengamanatkan Pemerintah mengusahakan dan menyelenggarakan satu sistem pendidikan nasional yang meningkatkan keimanan dan ketakwaan kepada Tuhan Yang Maha Esa serta akhlak mulia dalam bangsa yang diatur dengan undang-undang. Oleh karena itu, sistem pendidikan nasional harus mampu menjamin pemerataan kesempatan pendidikan, peningkatan mutu serta relevansi dan efisiensi manajemen pendidikan untuk menghadapi tantangan sesuai dengan tuntutan perubahan kehidupan lokal, nasional, dan global sehingga perlu dilakukan pembaharuan pendidikan secara terencana, terarah, dan berkesinambungan. Sejalan dengan itu Undang-undang Nomor 2 Tahun 1989 tentang Sistem Pendidikan Nasional tidak memadai lagi dan perlu diganti serta perlu disempurnakan agar sesuai dengan amanat perubahan Undang-Undang Dasar Negara Republik Indonesia Tahun 1945.

Hakekat pendidikan Indonesia dapat di lihat pada pasal 3 UU No.20 Tahun 2003, yang menyebutkan bahwa Pendidikan Nasional berfungsi mengembangkan kemampuan dan membentuk watak serta peradaban bangsa yang bermartabat dalam rangka mencerdaskan kehidupan bangsa, bertujuan untuk berkembangnya potensi peserta didik agar menjadi manusia yang beriman dan bertakwa kepada Tuhan Yang Maha Esa, berakhlak mulia, sehat, berilmu, cakap, kreatif, mandiri, dan menjadi warga negara yang demokratis serta bertanggung jawab. Pernyataan tersebut memperlihatkan bahwa esensi hakekat pendidikan adalah untuk meningkatkan kualitas manusia dan mengembangkan diri baik secara jasmaniah maupun rohaniah. Oleh karena itu, pendidikan dituntut untuk menghasilkan manusia yang dapat memajukan masyarakatnya; Tidak menjadi orang yang lekas puas, tetapi menjadi orang yang bermotivasi untuk terus belajar.

Tujuan pendidikan memiliki dua kata kunci, yaitu "mencerdaskan" dan "mengembangkan" manusia. Oleh karena itu penyelenggaraan pendidikan diarahkan untuk menghasilkan manusia Indonesia yang mempunyai keimanan dan bertaqwa, sehat jasmani dan rohani, memiliki pengetahuan dan keterampilan, berkepribadian yang mantap dan mandiri, memilki rasa tanggung jawab kemasyarakatan dan kebangsaan. Untuk mewujudkan apa yang terkandung pada hakekat dan tujuan pendidikan tersebut, pendidikan dilakukan melalui pendidikan keluarga, pendidikan dasar menengah dan pendidikan tinggi.

Pendidikan Dasar diselenggarakan untuk mengembangkan sikap dan kemampuan serta memberikan pengetahuan dan keterampilan dasar yang 
diperlukan untuk hidup dalam masyarakat serta mempersiapkan peserta didik yang memenuhi persvaratan untuk mengikuti pendidikan menengah. Pendidikan dasar ditekankan pada penguasaan sikap, kemampuan, pengetahuan dan keterampilan dasar untuk dapat hidup dalam masyarakat dan bagi yang memenuhi persyaratan disiapkan untuk mengikuti pendidikan menengah. Rumusan fungsi pendidikan dasar ini sangat penting untuk dicermati. Tekad bangsa Indonesia untuk mewajibkan setiap warga negara memperoleh pendidikan serendah-rendahnya pada tingkat pendidikan dasar adalah agar setiap warga negara Indonesia : (1) dapat-survive, (2) dapat berpartisipasi dalam pembangunan masyarakatnya, (3) dapat menjadi warga negara yang baik, (4) dapat memperoleh pekerjaan dan penghidupan yang bermartabat, (5) dapat mengembangkan dirinya sesuai dengan tuntutan perubahan masyarakat, (6) dapat mengambil keputusan berdasarkan informasi dan, (7) dapat terus belajar sepanjang hayat, serta (8) bagi yang memenuhi syarat dapat melanjutkan pendidikan kejenjang pendidikan menengah.

Sejalan dengan itu, penelitian ini akan menganalisis Sekolah Dasar Negeri Percontohan (SDNP) kompleks IKIP Rawamangun Jakarta Timur. Sekolah ini mempunyai sejarah/perjalanan yang panjang untuk sampai kesituasi dan kondisi seperti saat ini. Pola pembinaan guru di sekolah ini telah banyak ditiru oleh sekolah lain. Sekolah-sekolah yang menjadi binaan adalah SDS Pertamma, SDS Krakatau Steel, SDS Pupuk Bontang, SDS YKB Batam, SDS Yayasan Pendidikan Jaya, SDS Al Azhar Kelapa Gading. Beberapa sekolah yang memagangkan guru-gurunya di sekolah ini yaitu SDS Pupuk Bontang dan SDS Yayasan Pendidikan Java Bintaro. Sampai saat ini SDNP Kompleks IKIP sukses membina kerjasama yang baik dan serasi dengan seluruh orang tua murid yang tergabung dalam POMG atau BP3. Orang tua tidak hanya berperan dalam membantu pengadaan prasarana dan sarana tetapi juga membantu dalam kegiatan ekstrakurikuler, meningkat mutu serta menciptakan lingkungan yang kondusif.

\section{Masalah}

Kemajuan IPTEK selalu akan menjadi kesenjangan antara harapan dan kenyataan. Sekolah tidak pernah dapat mengharapkan peran orang tua yang sangat besar terhadap sekolah, tidak selalu terakomodasi dengan peraturan yang ada. Masyarakat dan orang tua menginginkan mutu, baik dalam hal prasarana/sarana maupun KMB. Disisi lain dana dari Pemerintah terbatas. Menghimpun dana dari orang tuapun telah ada rambu-rambunya. Dengan melihat kondisi real (kenyataan) dan hal yang diharapakan pada Pendidikan Dasar, maka timbul pertanyaan-pertanyaan yang merupakan permasalahan sebagai berikut:

1) Upaya apa yang dapat dilaksanakan sehingga mutu SDNP Kompleks SKIP tetap meningkat. Bagaimana menggalang kesatuan pendapat dengan seluruh masyarakat orang tua?

2) Upaya apa yang dapat dilakukan supaya kualitas guru sesuai dengan kriteria yang telah ditetapkan oleh Lab School IKIP? 
3) Upaya apa yang dapat dilakukan sehingga Program Belaiar Tuntas dan Maju Berkelanjutan disertai dengan pendekatan siswa belajar aktif, mandiri dan kreatif dapat terlaksana dengan baik ?

\section{Tujuan Penelitian}

Penelititan ini dilakukan untuk menganalisis Perencanaan Strategi (RENSTRA) Pendidikan pada Sekolah Dasar Negeri Percontohan (SDNP) Kompleks IKIP Rawamangun Jakarta. Sifat penelitian ini adalah suatu study kasus, dengan pengertian lain apakah SDNP IKIP Rwmangun dalam membangun dan meningkatkan mutu SDNP telah menggunakan Rencana Strategis (RENSTRA) secara benar.

\section{B. Gambaran Umum SDN Percontohan Kompleks IKIP Rawamangun, Jakarta}

Tahun 1968 IKIP Jakarta membuka satu sekolah dan diberi nama LABORATORY SCHOOL yang terdiri dari TK, SD, SMP, dan SMA Pendidikan sekolah tersebut berdasarkan Surat Keputusan Direktur Jenderal Perguruan Tinggi Nomor: 111 tahun 1968 tanggal 20 November 1968. Sekolah ini berfungsi sebagai Laboratorium Mahasiswa IKIP dalam melaksanakan praktek mengajar, penelitian Dosen dan inovasi pendidikan. Pada tahun 1968 tersebut baru ada SMP, SMA dan SPG.

Tahun 1969 TK dan SD dari Yayasan Putra Sejahtera yang didirikan oleh Ibu-ibu warga Kompleks UI-IKIP dan Depdikbud, berkawasan di Kompleks IKIP-UI bersatu dengan sekolah dibawah LABORATORY SCHOOL. IKIP Jakarta menerima keseluruhan dari sekolah ini termasuk janji IKIP mengangkat guru-gurunya menjadi PNS.

Tahun 1972 sekolah menerima tugas-tugas Proyek dari Departemen P\&K (nama Proyek TPK) untuk mencoba ide-ide baru dalam pendidikan yang pada saat itu berupa "COMPEREHENSHIVE SCHOOL" yaitu SD, SMP, dan SMA. Sedang TK dan SPG tidak menerima tugas proyek, maka diterapkan pendidikan dasar 8 tahun (5 tahun di SD \& 3 tahun di SMP). Sebagai sekolah Proyek maka Laboratory School bukan lagi menjadi tempat praktek mengajar bagi Mahasiswa IKIP.

Tahun 1974, SPG tidak lagi menerima siswa baru, hanya tinggal menyelesaikan kelas-kelas yang sudah ada. Tahun 1974 Proyek Tempat Pembinaan Keterampilan (TPK) dilanjutkan dengan Proyek Perintis Sekolah Pembangunan (PPSP). Proyek ini untuk mengujicobakan beberapa ide-ide dalam pendidikan untuk memberikan masukan bagi pembaharuan pendidikan nasional. Di Indonesia ada 8 PPSP (berada pada 8 IKIP se Indonesia), yaitu PPSP Jakarta, Bandung, Semarang, Yogyakarta, Surabaya, Malang, Ujung Pandang dan Padang. Diantara sekolah ini hanya SDNP IKIP yang tetap menjalankan apa yang telah diujicobakan dengan hasil baik. PPSP IKIP Malang hancur setelah tahun 1986. Padahal diantara 8 Proyek, Lab School/PPSP Malang adalah terbaik.

Mulai tanggal 1 Juni 1976 nama Laboratory School menjadi Sekolah Laboratorium Kependidikan IKIP Jakarta PPSP di Jakarta. Ini berdasarkan Surat Keputusan Rektor IKIP Jakarta No. 1S0/SP/1976 tanggal 20 Mei 1976. 
Penggantian nama tersebut untuk menunjang kebijaksanaan pemerintah dalam rangka perkembangan bahasa Indonesia.

\section{Kurikulum dan KBM 1969 s/d 1974}

Para siswa mengikuti Kegiatan Belajar Mengajar (KBM) sesuai dengan Kurikulum yang berlaku saat itu. Tahun 1969 s/d 1974 Lab School menggunakan Kurikulum 1968 ditambah dengan beberapa pembaharuan. Antara lain pembelajaran Bahasa Indonesia dengan metode SAS dan lembaga kata. Pengenalan konsep matematika atau yang dikenal dengan Matematika Modern. Hal ini ditafsirkan keliru oleh banyak sekolah negeri, seperti misalnya tidak perlu menghafal perkalian, menghilangkan kegiatan mencongak. Hal ini sangat melemahkan kemampuan dasar berhitung yang juga sebagai dasar matematika. Di SD Lab School IKIP kegiatan berhitung menguasai perkalian dan mencongak tetap dilaksanakan. Siswa belajar sesuai dengan kemampuan masing-masing. Siswa dilayani guru sesuai dengan kemampuan dan kecepatan masing-masing, sehingga dalam satu kelas memungkinkan program KBM siswa yang satu berbeda dengan yang lain.

\section{Kurikulum PPSP dan Krikulum 1975 (1975 s/d 1984)}

Sejak Januari 1975 s/d Juni 1984 digunakan Kurikulum + GBPP PPSP. Dengan menggunakan modul diterapkan cara belajar aktif, mandiri dengan sistim belajar tuntas dan maju berkelanjutan. Metode yang digunakan adalah multi metode. Artinya guru memilih metode yang sesuai dengan Proses Belajar Mengajar yang diperlukan sesuai dengan tujuan. Metode yang digunakan bervariasi antara lain ceramah, tanya jawab, penugasan, diskusi, kerja kelompok, metode proyek, atau integrated, demontrasi, eksperimen, sosio drama, bermain peran, dan lain-lain.

\section{Kurikulum 1984 (1984 s/d 1994)}

Kurikulum 1984 yang disebut Kurikulum 1975 yang disempurnakan sebenarnya adalah Kurikulum PPSP yang dinasionalkan, kecuali Bahasa Indonesia. Kurikulum/GBPP Bahasa Indonesia PPSP lebih sederhana, mudah dilaksanakan, mengutamakan kegunaan (sesuai dengan tujuan pembelajaran bahasa di SD). Modulpun tidak lagi efektif penggunaannya karena Squence Kurikulum PPSP berbeda dengan kurikulum 1984. Jika perbedaan itu ada dalam 1 (satu) cawu tidak masalah, tetapi perubahan itu ada antar tingkat kelas. Lebih-lebih modul Bahasa Indonesia jauh berbeda dengan GBPP 1984. Hal ini menjadi penyebab terhambatnya pelaksanaan program maju berkelanjutan dan pengembangan program anak berbakat yang mulai dilaksanakan tahun 1983.

\section{Kurikulum/GBPP 1994}

GBPP inipun diberlakukan secara bertahap. Tahun 1994 dilaksanakan dikelas I dan IV, tahun 1995 dikelas II dan V dan tahun 1996 baru dilaksanakan secara menyeluruh. Disimak dari sisi materi hampir tidak ada perubahan, yang ada adalah tukar tempat di sana-sini. Hal yang sukar dilaksanakan guru terdapat pada kurikulum/GBPP Bahasa Indonesia. 
Belum semua guru dapat memadukan butir pembelajaran, tema, struktur, ejaan, dan lain-lain. Terlaksananya kurikulum ini sangat tergantung pada kemampuan kreativitas guru.

\section{Suplemen Kurikulum / GBPP 1994 Yang Disempurnakan}

Hasil pengamatan Suplemen Kurikulum/GBPP 1994 menunjukan penelitian yang lebih jauh. Contoh : IPS kelas V tentang PBB, dalam Suplemen materi ini dipindah ke kelas VI. Menurut pengalaman sebaiknya dikelas VI itu banyak waktu untuk mengulang. Dilihat dari sisi waktu yang ada dikelas $\mathrm{V}$ tidak ada masalah asalkan cara penyampaiannya secara baik misalnya bermain peran, jadi materi itu tidak perlu dipindah ke kelas VI, Suplemen ini mulai dilaksanakan 1 Desember 1994.

\section{Langkah-Langkah Filosofi / Landasan Institusuinal Perencanaan Strategi} SDNP Kompleks IKIP Jakarta merupakan salah satu SD percontohan di Jakarta. Sebagai salah satu sekolah percontohan, sekolah ini memiliki kelas unggulan, kelas regular, kelas remidial, dan kelas percepatan. Kelas-kelas tersebut merupakan wadah untuk membantu dan perkembangan jasmani dan rohani anak didik susuai dengan sifat-sifat alami anak.

Program kegiatan yang terpadu antara pembentukan perilaku dan pengembangan kemampuan dasar, mengacu pada komponen-komponen seperti: belajar mandiri dengan media modul, belajar tuntas, maju berkelanjutan, pendekatan CBSA dengan pengembangan keterampilan proses, belajar kelompok, learning by doing, learning by playing, learning by know, learning to do, learning to be, dan learning to life together. Pembentukan perilaku merupakan kegiatan yang dilakukan secara tarus-menerus dan ada dalam kehidupan sehari-hari, sedangkan kegiatan pengembangan kemampuan dasar adalah kegiatan yang dipersiapkan untuk mencapai kemampuan-kemampuan tertentu sesuai dengan tahap perkembangan anak, dengan menggunakan metode bermain sambil belajar serta sistem CBSA (Cara Belajar Siswa Aktif) yaitu: klasikal, kelompok, dan individual.

Dari uraian diatas maka core business pendidikan pada SDNP dapat dirumuskan sebagai berikut.

\section{Core Business SDNP Kompleks IKIP Jakarta}

\begin{tabular}{|c|c|c|c|c|c|}
\hline Business & $\begin{array}{c}\text { Jasa yang } \\
\text { ditawarkan }\end{array}$ & Provider & Standar Measure & $\begin{array}{c}\text { Core } \\
\text { Business }\end{array}$ & $\begin{array}{c}\text { Defined in } \\
\text { Term of }\end{array}$ \\
\hline SD & \begin{tabular}{ll}
\multicolumn{2}{l}{ Pendidikan } \\
Dasar: \\
- & Kelas \\
& Unggulan \\
- & Kelas \\
& Reguler \\
- Kelas & Reuridial \\
& Kelas \\
& Percepatan
\end{tabular} & $\begin{array}{c}\text { Anak } \\
\text { usia } \\
0-12\end{array}$ & $\begin{array}{l}\text { Mengembangkan: } \\
\text { 1. Pembentukan } \\
\text { perilaku didasarkan } \\
\text { pada : } \\
\text { - Agama } \\
\text { - Moral } \\
\text { - Perasaan/emosi } \\
\text { - Kemampuan } \\
\text { bermasyarakat } \\
\text { - Disiplin. } \\
\text { 2. Kemampuan } \\
\text { Dasar: } \\
\text { - Daya Cipta } \\
\text { - Bahasa }\end{array}$ & $\begin{array}{l}\text { Pendidikan } \\
\text { Dasar } \\
\text { Umum } \\
\text { Unggulan }\end{array}$ & $\begin{array}{l}\text { Sikap \& } \\
\text { Kemampuan }\end{array}$ \\
\hline
\end{tabular}




\begin{tabular}{|l|l|l|l|l|l|}
\hline & & $\begin{array}{l}\text { - Daya Pikir } \\
- \text { Keterampilan } \\
\text { - Jasmani }\end{array}$ & & \\
\hline
\end{tabular}

\section{Core Competence}

Core Competence merupakan sekumpulan kemampuan yang dapat dipergunakan organisasi untuk melayani pelanggan secara unik dan dipergunakan sebagai basis untuk memenangkan persaingan. SDNP memiliki Competence pada program kurikuler, program penunjang, dan program ekstra kurikuler. Hal ini dapat dilihat pada Bab II tentang Gambaran Umum SDNP Kompleks IKIP Rawamangun.

\section{CORE COMPETENCE SDNP KOMPLEKS IKIP JAKARTA}

\begin{tabular}{|c|c|c|c|}
\hline POLA PIKIR & $\begin{array}{c}\text { KOMPETENSI / INTI } \\
\text { PROGRAM KURIKULER }\end{array}$ & $\begin{array}{c}\text { KOMPETENSI/INTI } \\
\text { PROGRAM } \\
\text { PENUNJANG } \\
\end{array}$ & $\begin{array}{c}\text { PROGRAM } \\
\text { KOMPETENSI INTI / } \\
\text { EKSTRAKURIKULER } \\
\end{array}$ \\
\hline $\begin{array}{l}\text { Fungsi Core } \\
\text { Business }\end{array}$ & $\begin{array}{l}\text { 1. Pembentukan Perilaku } \\
\text { a. Agama } \\
\text { b. Moral } \\
\text { c. Perasaan Emosi } \\
\text { d. Kemampuan } \\
\text { bermasyarakat } \\
\text { e. Disiplin } \\
\text { 2. Mengembangkan } \\
\text { Kemampuan dasar } \\
\text { a. Daya cipta/belajar aktif } \\
\text { b. Bahasa Inggris } \\
\text { c. Daya berfikir / } \\
\text { d. Katematika modern } \\
\text { e. Keterampilan } \\
\text { e. Komputer }\end{array}$ & $\begin{array}{l}\text { Pendukung kegiatan } \\
\text { kurikuler. Kemampuan } \\
\text { Sosialisasi, Apresiasi, } \\
\text { Berkreasi melalui: } \\
\text { a. Eksperimen } \\
\text { b. Eksplorasi } \\
\text { c. Study banding } \\
\text { d. Mengundang tamu } \\
\text { e. Pesta CBSA } \\
\text { f. Bermain peran } \\
\text { g. PBB } \\
\text { h. Widya wisata }\end{array}$ & $\begin{array}{l}\text { Mengembangkan hobi atau } \\
\text { ketrampilan tertentu: } \\
\text { a. OR (Berenang) } \\
\text { b. Melukis } \\
\text { c. Drum Band } \\
\text { d. Kesenian }\end{array}$ \\
\hline
\end{tabular}

\section{Visi SDNP kompleks IKIP Rawamangun Jakarta}

Visi merupakan gambaran yang jelas dan apa yang ingin dicapai dan diwujudkan pada masa depan tertentu (time frame). Visi menekankan tentang "apa" dan tentang "persepsi". Visi harus inspirasi, mampu memotivasi, mampu mengorbankan semangat seluruh jajaran perusahaan/organisasi, memberi arahan yang jelas, meletakan landasan system nilai, mampu memantapkan sinergitas.

Jadi visi adalah pandangan ideal masa depan yang ingin diwujudkan, dan secara potensial untuk terwujud kemana dan apa yang diwujudkan organisasi dimasa depan. Visi organisasi haruslah visi bersama, yang mampu menarik, menggerakan anggota organisasinya untuk komit terhadap visi tersebut. Karena itu, perumusan pernyataan visi yang dilakukan oleh sekelompok eksponen organisasi tersebut perlu secara intensif dikomunikasikan kepada segenap anggota organisasi, sehingga semuanya merasa sebagai pemilik visi tersebut.

Adapun kriteria visi diantaranya: bukan fakta tetapi gambaran pandangan ideal masa depan yang ingin diwujudkan; Dapat memberikan arahan dan mendorong anggota organisasi menunjukan kinerja yang baik; Dapat menimbulkan inspirasi dan siap menghadapi tantangan; Menjembatani masa kini dan masa mendatang; gambaran yang realistis dan kredibel. Dengan masa depan yang menarik; Sifatnya tidak statis dan tidak 
selamanya. Oleh karena itu, rumusan visi, cukup singkat dan mudah diingat; dirumuskan secara adhoc organisasi dan secara intensip dikomunikasikan pada para anggota; merupakan visi bersama; rumusan visi yang tepat akan menimbulkan energi dan komitmen; rumusan visi yang tepat akan memberikan makna bagi kehidupan dan memantapkan suatu standar keunggulan.

Adapun visi SDNP kompleks IK1P Rawamangun Jakarta: pengemban amanat UUD 1945 dan UU Pendldlkan Nasional untuk mewujudkan manusia Indonesia yang cerdas, beriman, bertakwa dan berilmu.

\section{MISI SDNP Kompleks IKIP Rawamangun Jakarta}

Misi merupakan pernyataan mengenai hal-hal yang harus dicapai organisasi bagi pihak-pihak yang berkepentingan dimasa datang. Pernyataan misi mencerminkan tentang segala sesuatunya penjelasan tentang bisnis/produk atau pelayanan yang ditawarkan yang sangat diperlukan oleh masyarakat untuk penyampaian visi. Dengan pernyataan misi dijelaskan mengapa organisasi perlu eksis dan bermakna dimasa yang akan datang.

Sejalan dengan itu misi menurut Inpres No. 7 tahun 1999, adalah suatu yang harus diemban atau dilaksanakan oleh Instasi Pemerintah, sesuai visi yang ditetapkan, agar tujuan organisasi dapat terlaksana dan berhasil dengan baik. Dengan pernyataan misi tersebut diharapkan seluruh pegawai dan pihak yang berkepentingan dapat mengenai Instansi pemerintah, dan mengetahui peran dan program-programnya, serta hasil yang akan diperoleh diwaktu-waktu yang akan datang.

Kriteria misi mencakup: Penjelasan tentang bisnis/produk atau pelayanan yang ditawarkan yang sangat diperlukan oleh masyarakat; Harus jelas memiliki sasaran publik yang akan dilayani; Kualitas produk dan pelayanan yang ditawarkan memiliki daya saing yang meyakinkan masyarakat; Penjelasan aspirasi bisnis yang diinginkan pada masa datang, juga manfaat dan keuntungannya bagi masyarakat dengan produk dan pelayanan yang tersedia. Perumusan misi merupakan hakikat didirikannya organisasi yang dapat mencakup: penggambaran tentang tujuan pembentukan organisasi kegiatan-kegiatan dan kiat-kiat organisasi; Merupakan pondasi penyusunan perencanaan strategis dan menunjukan pentingnya organisasi; Harus jelas menyatakan kepedulian organisasi terhadap kepentingan pelanggan; dapat mengundang partisipasi masyarakat luas terhadap perkembangan bidang utama yang digeluti organisasi.

Adapun misi SDNP Kompleks IKIP Rawamangun :

1. Meningkatkan mutu guru

2. Meningkatkan pendidikan dan pembelanjaan pada anak didik

3. Meningkatkan berbagai jenis baik untuk guru maupun siswa (anak didik)

4. Penyediaan sarana dan prasarana untuk kegiatan baik intra kurikuler maupun ekstra kurikuler

5. Memperluas wawasan melalui kegiatan diluar sekolah.

5. Nilai-Nilai Organisasi di SDNP Kompleks IKIP Rawamangun Jakarta Nilai adalah ukuran yang mengandung kebenaran/kebaikan mengenai 
keyakinan perilaku organisasi yang paling dianut dan digunakan sebagai budaya kerja dalam pengambilan keputusan dan peiaksanaan kegiatan misi dan visi organisasi.

Kriteria nilai mencakup: Faktor penggerak perilaku organisasi dan mendorong keunggulan karyawan/individu dalam organisasi; Dalam mengklarisifikasi ekspektasi kinerja mutu; menghargai pelanggan supplier, vendor dan masyakat luas; Perilaku pimpinan sehari-hari sebagai teladan saat menentukan pencapaian visi dan misi.

Makna nilai-nilai (Values) bagi organisasi terdiri dari:

1. Togethernees. Bekerja dalam kebersamaan jauh lebih baik daripada bekerja sendiri-sendiri.

2. Empaty. Memahami dan ikut merasakan masalah yang dihadapi orang lain.

3. Assist. Kesediaan untuk selalu memberikan secara ikhlas.

4. Maturity. Kematangan dalam mengatasi permasalahan maupun tantangan bersama.

5. Willingness. Kesediaan bekerjasama berdasarkan persahabatan atau kooperatif.

6. Organizational. Perilaku secara organizational yakni interaksi satu sama lain dalam memecahkan masalah ataupun krisis.

7. Respect. Saling menghormati serta menghargai sesama yang lain.

8. Kindness. Berperilaku santun, rendah diri, serta selalu memberikan kesejukan dalam setiap pertemuan.

9. Integritas. Menanamkan rasa hormat kepada orang lain.

10. Inovatif. Menjaga dan melanjutkan tradisi inovasi;

11. Keunggulan. Keyakinan untuk selalu yang terbaik.

12. Flexibily: Resiliece, Mastering Change.

13. Wisdom. sikap dan perilaku yang berorientasi pada prinsip keseimbangan/keharmonisan antara rasionalitas dan moralitas, otak kiri dan otak kanan.

Sehingga rumusan nilai merupakan penjelasan bagaimana dalam sehari-harinya melakukan tugas memimpin organisasi; Sikap saling menghormati serta menghargai terhadap sesama yang lain berperilaku santun, rendah hati dan memberikan kesejukan dalam setiap pertemuan, menanamkan rasa hormat pada orang lain terutama sikap menghargai pelanggan, supplier, vendor, dan masyarakat luas.

Adapun nilai-nilai SDNP Kompleks I KIP Rawamangun Jakarta :

1. Kepribadian

2. Kemampuan

3. Dedikasi

4. Kepeloporan

5. Pangabdian masyarakat

\section{Tujuan SDNP Kompleks SDNP IKIP Rawamangun Jakarta}

Tujuan itu memberi arah atas hasil yang akan dicapai dengan jangka waktu lebih panjang dan sasaran, tergantung tingkat organisasinya dan memuat apa dan kapan sesuatu akan dicapai serta mendorong kinerja.

Tujuan mempunyai kriteria harus serasi dan mengklarifikasi visi, misi dan 
nilai- nilai organisasi; Dapat memenuhi atau berkontribusi untuk memenuhi misi, program dan sub program organisasi; Menangani hasil-hasil penilaian lingkungan internal/ekstemal dan yang diprioritaskan, serta mugkin dikembangkan dalam menangani isu-isu stratejik, Cenderung untuk secara esensial tidak berubah, sehingga terjadi pergeseran lingkungan, atau dalam hal isu stratejik hasil yang diinginkan telah dicapai, Secara relatif berjangka panjang, yaitu sekurang-kurangnya 3 tahun atau lebih tujuan organisasi yang dapat dicapai sebelum masa 3 tahun lebih tepat disebut sasaran; Dapat mengatasi kesenjangan antara tingkat pelayanan saat ini dengan yang didambakan; Menggambarkan hasil program/sub program yang diinginkan; Menggambarkan arah yang jelas dari organisasi, program dan sub program, tetapi tidak menetapkan ukuran-ukuran spesifik atau strategi. Hal ini akan dilakukan oleh sasaran dan "Action"; Merupakan otoritas legislatif, atau memiliki legislasi yang mendukungnya, seperti halnya sasaran; Harus menantang namun realistis yang dapat dicapai.

Adapun tujuan SDNP Kompleks IKIP Rawamangun Jakarta :

a) Meningkatkan pendidikan dan pengajaran untuk mengembangkan bakat anak didik sesuai dengan kemampuannya.

b) Membantu mencapai cita-cita yang diharapkan.

c) Memberi bekal pada anak didik untuk mencapai prestasi unggul di DKI Jakarta.

d) Mencapai rata-rata UAS (Ujian Akhir Semester): 8 (Delapan). 


\section{ANALISIS}

\section{Analisis Lingkungan Internal}

\section{TABLE RERUMUSAN LINGKUNGAN INTERNAL SDN PERCONTOHAN KOMPLEKS IKIP JAKARTA}

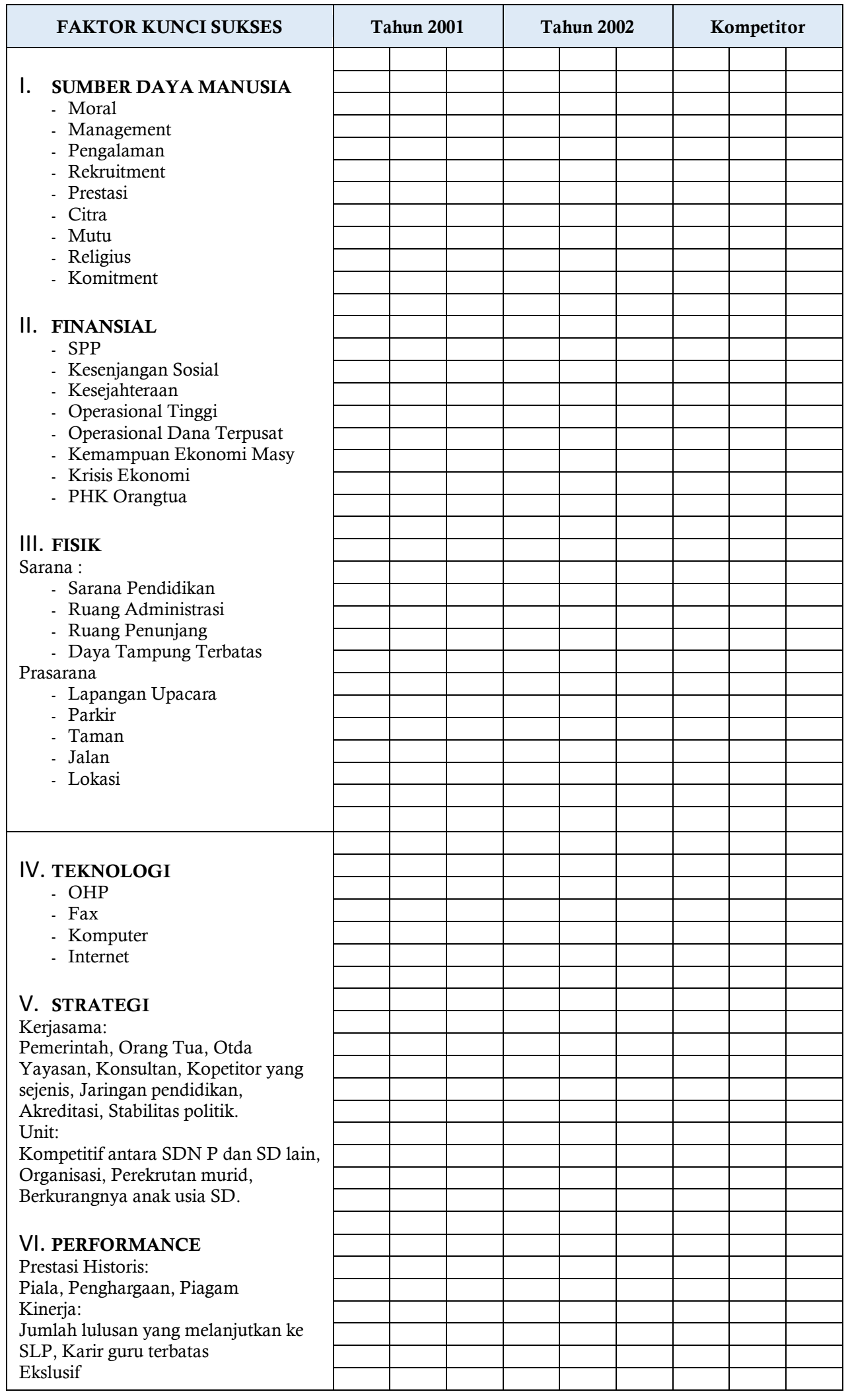




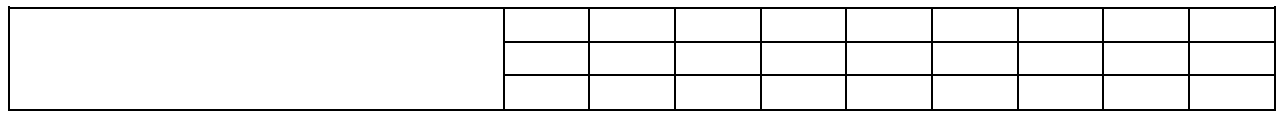

2. Analisa Lingkungan Eksternal

TABEL PERUMUSAN LINGKUNGAN EKSTERNAL SDN PERCONTOHAN KOMPLEKS IKIP RAWAMANGUN

\begin{tabular}{|c|c|c|c|c|c|c|c|c|c|c|}
\hline \multirow{3}{*}{ FAKTOR KUNCI SUKSES } & \multicolumn{5}{|c|}{ PELUANG } & \multicolumn{5}{|c|}{ ANCAMAN } \\
\hline & \multicolumn{3}{|c|}{$\begin{array}{c}\text { Probabilitas } \\
\text { Sukses }\end{array}$} & \multicolumn{2}{|c|}{$\begin{array}{c}\text { Daya } \\
\text { Atraktif }\end{array}$} & \multicolumn{3}{|c|}{$\begin{array}{c}\text { Probabilitas } \\
\text { Terjadi }\end{array}$} & \multicolumn{2}{|c|}{$\begin{array}{l}\text { Daya } \\
\text { Rusak }\end{array}$} \\
\hline & $\mathbf{T}$ & $\mathbf{S}$ & $\mathbf{R}$ & $\mathbf{T}$ & $\mathbf{S}$ & $\mathbf{T}$ & $\mathbf{S}$ & $\mathbf{R}$ & $\mathbf{T}$ & $\mathbf{S}$ \\
\hline I. EKONOMI & & & & & & & & & & \\
\hline - Kemampuan Ekonomi & & & & & & & & & & \\
\hline - Krisis Ekonomi & & & & & & & & & & \\
\hline \multirow{5}{*}{$\begin{array}{ll}\text { II. } & \text { SOSIAL } \\
\text { - Kompetitor Sejenis } \\
\text { - Kesenjangan Sosial } \\
\text { - Jaringan Pendidikan } \\
\text { - Tingkat Pertumbuhan } \\
\text { Penduduk } \\
\text { - Akreditasi } \\
\text { - Perekrutan Orangtua }\end{array}$} & & & & & & & & & & \\
\hline & & & & & & & & & & \\
\hline & & & & & & & & & & \\
\hline & & & & & & & & & & \\
\hline & & & & & & & & & & \\
\hline \multirow{2}{*}{$\begin{array}{ll}\text { III. } & \text { POLITIK } \\
\text { - Otonomi daerah } \\
\text { - Stabilitas Politik }\end{array}$} & & & & & & & & & & \\
\hline & & & & & & & & & & \\
\hline \multirow{11}{*}{ IV. TEKNOLOGI } & & & & & & & & & & \\
\hline & & & & & & & & & & \\
\hline & & & & & & & & & & \\
\hline & & & & & & & & & & \\
\hline & & & & & & & & & & \\
\hline & & & & & & & & & & \\
\hline & & & & & & & & & & \\
\hline & & & & & & & & & & \\
\hline & & & & & & & & & & \\
\hline & & & & & & & & & & \\
\hline & & & & & & & & & & \\
\hline
\end{tabular}


3. Analisis SWOT

ANALISA STRATEGI DENGAN MATRIX SWOT SDN PERCONTOHAN KOMPLEK IKIP RAWAMANGUN

\begin{tabular}{|l|l|l|}
\hline Internal Factor & Strenght (S) & Weakness (W) \\
& S.1 Komitment & W.1 Daya Tampung terbatas \\
& S.2 Dana & W.2 Operasional Dana \\
& S.3 Sarana dan Prasarana & Terpusat \\
& S.4 Kesejahteraan & W.3 Biaya Operasional tinggi \\
& S.5 Organisasi & W.4 Karis Guru terbatas \\
& & W.5 Intervensi Yayasan \\
Eksternal Factor & & \\
& & \\
Oportunity (O) & Competitive Advantage (SO) & Mobilization (WO) \\
O.1 Kepercayaan Masyarakat & S.1 - O.1 & W.1 - O.1 \\
O.2 Religius & S.2-O.3 & W.2 - O.3 \\
O.3 Kemampuan Ekonomi & S.3-O.3 & W.3 - O.3 \\
Masyarakat & & \\
O.4 Akreditasi & & \\
O.5 Teknologi & & \\
\hline Threats (T) & Investment / Divasment (ST) & Damage Control (WT) \\
T.1 Kompetitor Sejenis & S.1 T.1 & W.1 - T.1 \\
T.2 Berkurangnya anak usia & S.1 - T.2 & W.2 - T.4 \\
SD & S.3-T.2 & W.5 - T.4 \\
T.3 Kesenjangan Sosial & & \\
T.4 Krisis Ekonomi & & \\
T.5 Penculikan murid & & \\
\hline
\end{tabular}

4. Analisa Faktor Internal - Eksternal

I. DATA SWOT (KEKUATAN - KELEMAHAN - PELUANG ANCAMAN)

A. KEKUATAN :

Komitmen

Prestasi

Citra

Mutu

Keamanan

Lokasi

Kesejahteraan

Sarana prasarana

Manajeman

Organisasi

Dana

Promosi

B. KELEMAHAN:

Eksklusif

Daya tampung terbatas

Retrutmen

Karier guru terbatas

Lokasi

Operasional dana terpusat

Operasional Tinggi

Intervensi Dinas Dikdas

Nepotisme
C. PELUANG:

Otda

Kepercayaan Masyarakat

Religius

Jaringan Pendidikan

Tingkat pertumbuhan penduduk

Teknologi

Kemampuan ekonomi masyarakat

Akriditas

D. ANCAMAN

Kompetitor

Krisis Ekonomi

Kesenjangan sosial

Perekrutan murid

Berkurang anak usia SD

Stabilitas politik

PHK orang tua 
1. ANALISA FAKTOR INTERNAL - EKSTERNAL SDNP KOMPLEKS IKIP RAWAMANGUN

a. FAKTOR INTERNAL

1. $\operatorname{KEKUATAN~(S)~}$

Komitmen

- Dana

- Sarana \& Prasarana

- Kesejahteraan

- Organisasi

2. KELEMAHAN (W)

- Daya tampung terbatas

- Operasional dana terpusat

- Biaya operasional tinggi

- Karir guru terbatas

Intervensi Dinas Dikdas

3. MATRIKS PENGAMBILAN KEPUTUSAN

Faktor Internal

\begin{tabular}{|c|l|c|c|c|c|c|c|}
\hline $\begin{array}{l}\text { N } \\
\text { O }\end{array}$ & A. ISU KEKUATAN & S1 & S2 & S3 & S4 & S5 & TOTAL \\
\hline 5 & S1 Komitmen & & X & X & X & X & 4 \\
\hline 6 & S2 Sarana \& Prasarana & & & X & O & X & 2 \\
\hline 7 & S3 Organisasi & & & & O & O & 0 \\
\hline 8 & S4 Dana & & & & & X & 1 \\
\hline 9 & S5 Kesejahteraan & 1 & 2 & 3 & 4 & 5 & \\
\hline & & & & & & & \\
& & 0 & 0 & 0 & 2 & 1 & \\
& Vertikal (kontak kosong = O) & 4 & 2 & 0 & 1 & 0 & \\
& Horizontal (X) & 4 & 2 & 2 & 3 & 1 & \\
\hline & Rotal & I & III & IV & II & IV & \\
\hline
\end{tabular}

Kesimpulan Rangking KEKUATAN:

I. Komitmen

II. Dana

III. Sarana \& Prasarana

IV. Kesejahteraan

V. Organisasi

\begin{tabular}{|c|l|c|c|c|c|c|c|}
\hline $\begin{array}{c}\text { N } \\
\text { O }\end{array}$ & A. ISU KELEMAHAN & W1 & W2 & W3 & W4 & W5 & TOTAL \\
\hline 5 & W1 Daya tampung terbatas & & X & X & X & X & 4 \\
\hline 6 & W2 Intervensi yayasan & & & $\mathrm{O}$ & O & O & 2 \\
\hline 7 & W3 Biaya Operasional tinggi & & & & O & X & 1 \\
\hline 8 & W4 Operasional dana terpusat & & & & & X & 1 \\
\hline 9 & W5 Karir Guru Terbatas & & & & & & 0 \\
\hline & & 1 & 2 & 3 & 4 & 5 & \\
& & & & & & & \\
& Vertikal (kontak kosong = O) & 0 & 0 & 1 & 2 & 1 & \\
& Horizontal (X) & 4 & 2 & 1 & 1 & 0 & \\
\hline & Total & 4 & 1 & 2 & 3 & 1 & \\
\hline
\end{tabular}

Kesimpulan Rangking KELEMAHAN:

I. Daya tampung terbatas

II. Intervensi yayasan

III. Biaya Operasional tinggi

IV. Operasional dana terpusat

V. Karir Guru Terbatas 


\section{b. FAKTOR EKSTERNAL}

\section{PELUANG}

Kepercayaan masyarakat

Religius

- Teknologt

- Kemampuan ekonomi masyarakat

Akreditasi

2. ANCAMAN

- Kopetitor sejenis

- Krieis ekonomi

- Kesenjangan sosial

Penculikan murid

- Keberhasilan Program

\section{MATRIKS PENGAMBILAN KEPUTUSAN}

\begin{tabular}{|c|l|c|c|c|c|c|c|}
\hline $\begin{array}{c}\text { N } \\
\text { O }\end{array}$ & A. ISU PELUANG & S1 & S2 & S3 & S4 & S5 & TOTAL \\
\hline 1 & 01 Kepercayaan Masyarakat & & $\mathrm{X}$ & $\mathrm{X}$ & $\mathrm{X}$ & $\mathrm{X}$ & 4 \\
\hline 2 & 02 Teknologi & & & $\mathrm{O}$ & $\mathrm{O}$ & $\mathrm{O}$ & 0 \\
\hline 3 & 03 Religius & & & & & $\mathrm{O}$ & 1 \\
\hline 4 & 04 Akreditas & & & & & & 0 \\
\hline 5 & 05 Kemampuan ekonomi masyarakat & 1 & 2 & 3 & 4 & 5 & \\
& & 0 & 0 & 1 & 1 & 2 & \\
& Vertikal (kontak kosong = O) & 4 & 0 & 2 & 0 & 0 & \\
& Horizontal (X) & 4 & 0 & 3 & 1 & 2 & \\
\hline & Total & & & & \\
\hline & Rangking / Urutan & I & III & IV & II & IV & \\
\hline
\end{tabular}

Kesimpulan Rangking PELUANG (O):

I. Kepercayaan Masyarakat

II. Religius

III. Kemampuan Ekonomi Masyarakat

IV. Akreditas

V. Teknologi

\begin{tabular}{|c|l|c|c|c|c|c|c|}
\hline $\begin{array}{l}\text { N } \\
\text { O }\end{array}$ & A. ANCAMAN & W1 & W2 & W3 & W4 & W5 & TOTAL \\
\hline 1 & T1 Kompetitor Sejenis & & $\mathrm{X}$ & $\mathrm{X}$ & $\mathrm{X}$ & $\mathrm{X}$ & 4 \\
\hline 2 & T2 Krisis Ekonomi & & & $\mathrm{O}$ & $\mathrm{X}$ & $\mathrm{O}$ & 1 \\
\hline 3 & T3 Kesenjangan Sosial & & & & $\mathrm{X}$ & $\mathrm{O}$ & 1 \\
\hline 4 & T4 Penculikan Murid & & & & $\mathrm{O}$ & 0 \\
\hline 5 & T5 Berkurangnya anak usia SD & & & & & & 0 \\
\hline & & 1 & 2 & 3 & 4 & 5 & \\
& & & & & & & \\
& Vertikal (kontak kosong = O) & 0 & 0 & 1 & 0 & 3 & \\
& Horizontal (X) & 4 & 1 & 1 & 0 & 0 & \\
\hline & Total & 4 & 1 & 2 & 0 & 3 & \\
\hline
\end{tabular}

Kesimpulan Rangking ANCAMAN (T):

I. Kompetitor Sejenis

II. Berkurangnya anak usia SD

III.Kesenjangan sosial

IV. Krisis ekonomi 
V. Penculikan murid

c. TABEL IFAS SDNP KOMPLEKS IKIP RAWAMANGUN

\begin{tabular}{|c|c|c|c|c|c|}
\hline $\begin{array}{c}\text { FAKTOR-FAKTOR } \\
\text { STRATEGIS INTERNAL }\end{array}$ & BOBOT & $\begin{array}{l}\text { RATIN } \\
\text { G }\end{array}$ & $\begin{array}{l}\text { BOBOT X } \\
\text { RATING }\end{array}$ & $\begin{array}{l}\text { PRIO } \\
\text { RITAS }\end{array}$ & KOMENTAR \\
\hline KEKUATAN & & & & & \\
\hline - Komitmen & 020 & 5 & 10 & & - Komitmen merupakan kekuatan untuk \\
\hline - Dana & & & & 2 & - Pengalokasian dana vang efektif dan \\
\hline & 0,15 & 4 & 0,60 & & efisien \\
\hline - Sarana \& Prasarana & & & & 3 & - Sarana dan prasarana menunjang KBM \\
\hline - Kesejahteraan & 0,15 & 3 & 0,45 & 4 & - Reward yang sesuai \\
\hline - Organisasi & $\begin{array}{l}0,05 \\
0,05\end{array}$ & $\begin{array}{l}3 \\
3\end{array}$ & $\begin{array}{l}0,15 \\
0,15\end{array}$ & 5 & - Organisasi yang solid \\
\hline Sub Total & 0,60 & & 2,35 & & \\
\hline KELEMAHAN & & & & & \\
\hline - Daya tampung & 0,15 & 4 & 0,60 & 1 & \\
\hline - Operasional dana terpusat & 0,10 & 4 & 0,40 & 2 & - Menambah ruang belajar \\
\hline - Biaya operasional tinggi & 0,06 & 3 & 0,18 & 3 & - Desentralisasi \\
\hline - Karir guru terbatas & 0,05 & 3 & 0,15 & 4 & - Efisiensi \\
\hline - Intervensi & 0,04 & 3 & 0,12 & 5 & $\begin{array}{l}\text { - Wakasek/kepsek/pengawas } \\
\text { - Pendelegasian }\end{array}$ \\
\hline Sub Total & 0,40 & & 1,45 & & \\
\hline TOTAL & 1,00 & & 3,80 & & \\
\hline
\end{tabular}

d. TABEL EFAS IKIP RAWAMANGUN

\begin{tabular}{|c|c|c|c|c|c|}
\hline $\begin{array}{c}\text { FAKTOR-FAKTOR } \\
\text { STRATEGIS INTERNAL }\end{array}$ & BOBOT & $\begin{array}{c}\text { RATIN } \\
\mathrm{G}\end{array}$ & $\begin{array}{l}\text { BOBOT X } \\
\text { RATING }\end{array}$ & $\begin{array}{l}\text { PRIO } \\
\text { RITAS }\end{array}$ & KOMENTAR \\
\hline $\begin{array}{l}\text { PELUANG (OPORTUNITY) } \\
\text { - Kepercayaan } \\
\text { - Religius } \\
\text { - Teknologi } \\
\text { - Kesejahteraan } \\
\text { - Organisasi }\end{array}$ & $\begin{array}{l}0,20 \\
0,15 \\
0,04 \\
0,10 \\
0,06\end{array}$ & $\begin{array}{l}5 \\
4 \\
\\
3 \\
4 \\
3 \\
\end{array}$ & $\begin{array}{c}1,0 \\
0,60 \\
\\
0,12 \\
0,40 \\
0,18 \\
\end{array}$ & $\begin{array}{l}1 \\
2 \\
3 \\
3 \\
4 \\
5\end{array}$ & $\begin{array}{l}\text { - Jaga kepercayaan masyarakat } \\
\text { - Meningkatkan pemahaman Agama Islam } \\
\text { - Mengaplikasikan Teknologi } \\
\text { - Mengoptimalkan Ekonomi Masyarakat } \\
\text { - Mempertahankan Akreditas }\end{array}$ \\
\hline Sub Total & 0,55 & & 2,30 & & \\
\hline 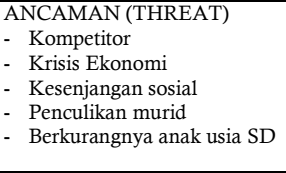 & $\begin{array}{l}0,15 \\
0,10 \\
0,06 \\
0,05 \\
0,04\end{array}$ & $\begin{array}{l}4 \\
4 \\
3 \\
3 \\
3\end{array}$ & $\begin{array}{l}0,60 \\
0,40 \\
0,18 \\
0,15 \\
0,12\end{array}$ & $\begin{array}{l}1 \\
2 \\
3 \\
4 \\
5\end{array}$ & $\begin{array}{l}\text { - Menambah ruang belajar } \\
\text { - Desentralisasi } \\
\text { - Efisiensi } \\
\text { - Wakasek/kepsek/pengawas } \\
\text { - Pendelegasian }\end{array}$ \\
\hline Sub Total & 0,45 & & 1,55 & & \\
\hline TOTAL & 1,00 & & 3,85 & & \\
\hline
\end{tabular}

e. PENENTUAN POSISI ORGANISASI

DIAGRAM POSITIONING IFAS DAN EFAS SDNP KONPLEKS IKIP RAWAMANGUN

PELUANG

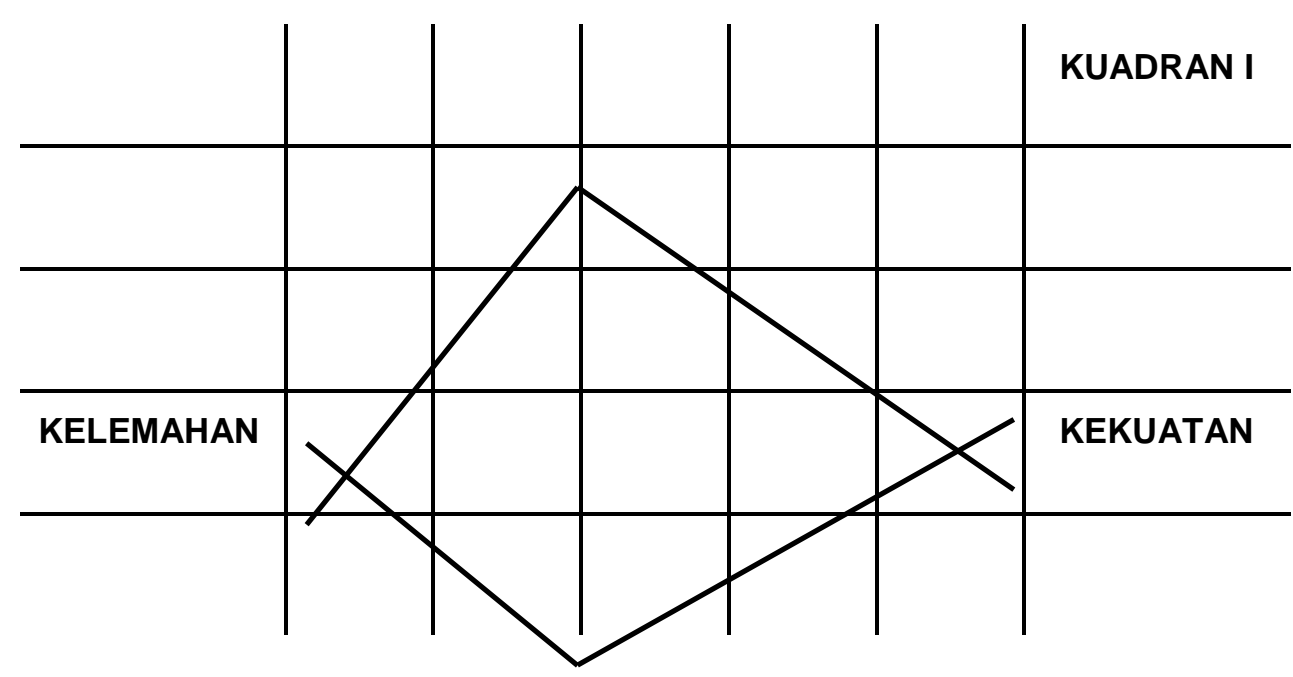




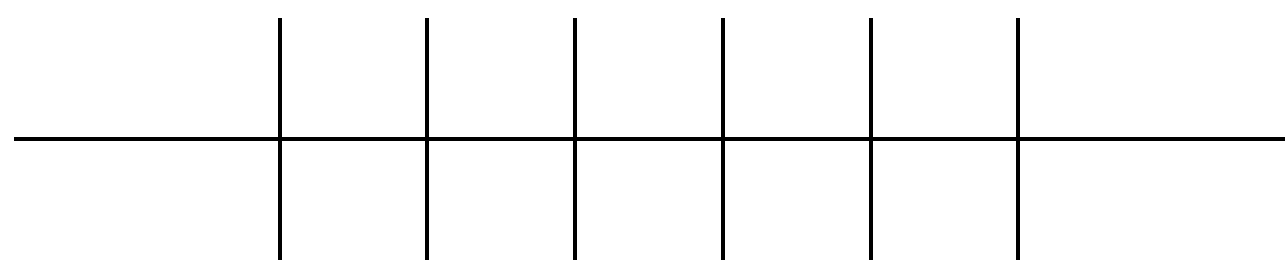

ANCAMAN

Berdasarkan sub jumlah Faktor Internal dan Faktor Eksternal, maka diketahui Posisi SDNP Kompleks IKIP Rawamangun sebagai berikut:

\begin{tabular}{|c|c|}
\hline INFAS & 3,80 \\
\hline KEKUATAN & 2,35 \\
\hline KELEMAHAN & 1,45 \\
\hline & 0,90 \\
\hline
\end{tabular}

\section{E. KESIMPULAN}

1. Ternyata pendekatan perencanaan strategi dapat diterapkan pada organisasi (Sekolah) SDNP Kompleks IKIP Rawamangun Jakarta. Hal ini diperkuat dan hasil analisis yang menggunakan analisis lingkungan maupun analisis SWOT.

2. Hasil kajian ini mengingatkan : apabila organisasi (sekolah) ingin mendapatkan mutu yang terbaik dapat menggunakan pendekatan Perencanaan Strategi maupun pendekatan Total Quality.

3. Dari hasil ANALISA FAKTOR INTERNAL - SDNP KOMPLEKS IKIP RAWAMANGUN FAKTOR INTERNAL.

Faktor KEKUATAN (S) rangking adalah sebagai berikut:

a. Komitmen Dana

b. Sarana \& Prasarana,

c. Kesejahteraan,

d. Organisasi.

Factor KELEMAHAN (W) rangking sebagai berikut :

a. Daya tampung terbatas ,

b. Operasional dana terpusat,

c. Biaya operasional tinggi,

d. Karir guru terbatas ,

e. Intervensi Dinas Dikdas

Faktor PELUANG (O) rangking sbb

a. Kepercayaan Masyarakat

b. Religius

c. Kemampuan Ekonomi Masyarakat

d. Akreditas

e. Teknologi

Faktor Rangking ANCAMAN (T) sebagai berikut :

a. Kompetitor Sejenis

b. Berkurangnya anak usia SD

c. Kesenjangan sosial

d. Krisis ekonomi

e. Penculikan murid 


\section{DAFTAR PUSTAKA}

Akdon. Strategic Management For Educational Management (Manajemen Stratejik untuk Manajemen Pendidikan). Bandung : Alfabeta. 2006.

Arikunto, Suharsimi; Suhardjono, dan Supardi. Penelitian Tindakan Kelas. Jakarta : Bumi Aksara. 2006.

Blanchard, Ken. Leader of The Future. New York: Jossey Bass Inc. 1996

Brounds, Greg et al. Total Quality Management. Singapore : Mc Graw-Hil Inc. 1997.

Buhler, Patricia. Alpha Teach Yourself, Management Skils, 24 jam. Diterjemahkan oleh Sugeng Haryanto cs. Edisi Pertama. Jakarta: Pranada. 2004.

Burus Jr, William J. Performance Measurement, Evaluation, and Incentives. Boston : Harvard Business School Press. 1992.

Carr, Wilfred and Stephen Kemmis. Becomming Critical. Education, Knowledge, and Action Research. Australia : Deokin University. 1997.

Covey, Stephen R. The 7 Habits of Highly Effective People. New York : Fire Side. 1990.

Prinsciple Centered Leadership. London : A Fire Book of Sihon \& Schuster Inc. 1992.

Crewell, John W. Qualitative Inquiry and Research Design. Choosing Among Five Traditions. USA : Sage Publications Inc. 1998.

Research Design. Qualitative, Quantitative, and Mixed

Methods Approaches. USA : Sage Publications Inc. 2003

Dinas Pariwisata Provinsi DKI Jakarta. Renstra 2004-2005

Domingo, Rene T. Quality Means Survival. Singapore : Simon \& Shauster (Asia) Pte Ltd. 1997.

Fitzsimmons, James A. and Mona J. Fitzsimmons. Service Management : Operations, Strategy, and Information Technology. Singapore : McGraw Hill International Editions. 1999.

Gamage, David T. and Nicholas S. Pang. Leadership and Management in Education. Hongkong: The Chinese University. 2003.

Gaspersz, Vincent. Total Quality Management. Jakarta : PT. Gramedia Pustaka Utama. 2005.

Gatewood, Robert D. and Robert R. Taylor. and O. C. Ferrel. Management: Comprehension, Analysis, and Application. Homewood, Illianois : Richard D. Irwin Inc. 1995.

Gibson, Ivancevich and Donnely. Organisasi dan Manajemen. Perilaku, Struktur, Proses. Edisi Keempat. Jakarta : Erlangga. 1984.

Harian Umum Surat Kabar Kompas, Tanggal 23 Maret 2006.

Ivancevich, John M. Human Resource Management. Tenth Edition. Singapore : Mc Graw Hill. Internation Edition. 2007

Kember, David. Action Learning and Action Research. USA : Deokin University. 2000 .

Kemmis, Stephen and Robin McTaggart. The Action Research Planner. Australia : Deokin University. 1990.

Laporan Tahunan Dinas Pariwisata Provinsi DKI Jakarta. 2005

Laporan Tahunan Pusat Penelitian dan Sertifikasi (PPSK) Dinas Pariwisata Provinsi DKI Jakarta. 2004,2005 dan 2006 2005. 
2006.

Lewis, Ralph G. and Douglas H. Smith. Total Quality in Higher Education. Florida : St. Lucie Press. 1994.

Lindsay, William M. and Joseph A. Petrick. Total Quality and Organization Development. Florida : St. Lucia Press. 1997.

Madya, Suwarsih. Teori dan Praktik Penelitian Tindakan. Action Research. Bandung : Alfabeta. 2006.

Mills, Geoffry E. Action Research. A Guide For The Teacher Researcher. Prentice Hall. 2000.

Newstrom, John W. and Keith Davis. Organizational Behavior, Human Behavior at Work. International Edition. Mc Graw-Hill. 2002.

Program Pascasarjana Universitas Negeri Jakarta. Pedoman Penulisan Tesis Dan Disertasi. Jakarta : Universitas Negeri Jakarta. 2005.

Pusdiklat Pegawai Depdiknas. Prinsip-Prinsip Manajemen Pelatihan : Analisa, Desain, Pengembangan, Pelaksanaan, Evaluasi. Depok : Pusdiklat Pegawai Depdiknas. 2003.

Rangkuti, Freddy. Measuring Customer Satisfaction. Jakarta : PT Gramedia Pustaka Utama. 2003.

Robbins, Stephen P. Perilaku Organisasi, Konsep, Kontrovensi, Aplikasi, Jilid I. Edisi Bahasa Indonesia, Edisi kedelapan. Jakarta : PT. Prenhalindo. 1996.

Sagala, Syaiful. Manajemen Berbasis Sekolah dan Masyarakat : Strategi Memenangkan Persaingan Mutu. Jakarta : PT. Rakarta Samarta. 2004.

Salusu. Pengambilan Keputusan Strategi Untuk Organisasi Publik dan Organisasi Non Profit. Jakarta : PT. Grasindo. 1996.

Stoner, James A. F, Edward Freeman, dan Daniel R. Gilbert Jr. Manajemen Jilid I. Edisi Bahasa Indonesia. New Jersey : Prentice-Hall Inc. 1996.

Stringer, Ernest T. Action Research Second Edition. London : Sage Publications. 1999.

Suardi, Rudi. Sistem Manajemen Terpadu. ISO 9000 : 2000. Jakarta : PT Remaja Rosdakarya. 2001.

Tenner, Arthur R. and Irving J. DeToro. Total Quality Management. Three Steps To Continuous Improvement. Massachusetts : Addison-Wesley Publishing Company. 1992.

Tjiptono, Fandy and Anastasia Diana. Total Quality Management. Yogyakarta : Andi. 2000.

Tillar, HAR. Pendidikan, Kebudayaan, dan Masyarakat Madani Indonesia : Strategi Reformasi Pendidikan Nasional. Bandung : Remaja Rosdakarya. 2000.

W.I.M, Poli dan Jason Jaya. Manajemen Mutu Terpadu. Program Pasca Sarjana Kerjasama Universitas Hasanudin dengan LAN. Sulawesi Selatan : Program Pasca Sarjana Kerjasama Universitas Hasanudian dengan LAN. 2000.

Wellington, Patricia. Kaizen Strategies for Customer Care. (Kepedulian Pada Pelanggan). Cara Menciptakan Program Kepedulian pada Pelanggan Yang Ampuh dan Menerapkannya. Alih Bahasa : Drs. Alexander Sindoro. Batam Center : Interaksara.

http://www.lib.virginia.edu/staff/management-information/sq981.html

Williams, Chuck. Management. United States of America : Thomson Learning. 2000. 